\title{
Solutions for ecosystem-level protection of ocean systems under climate change
}

\author{
Queiros Ana M. ${ }^{1,{ }^{*}}$, Huebert Klaus B. ${ }^{2,3}$, Keyl Friedemann ${ }^{4}$, Fernandes Jose A. ${ }^{1}$, Stolte Willem ${ }^{5}$, \\ Maar Marie ${ }^{5,6}$, Kay Susan ${ }^{1}$, Jones Miranda C. ${ }^{7}$, Hamon Katell ${ }^{8}$, Hendriksen Gerrit ${ }^{5}$, \\ Vermard Youen ${ }^{9}$, Marchal Paul ${ }^{9}$, Teal Lorna R. ${ }^{10}$, Somerfield Paul J. ${ }^{1}$, Austen Melanie C. ${ }^{1}$, \\ Barange Manuel ${ }^{1,11}$, Sell Anne F. ${ }^{3}$, Allen Icarus ${ }^{1}$, Peck Myron A. ${ }^{2}$
}

${ }_{1}^{1}$ Plymouth Marine Lab, Prospect PI, Plymouth PL1 3DH, Devon, England.

2 Univ Hamburg, Olbersweg 24, D-22767 Hamburg, Germany.

${ }^{3}$ Univ Maryland, Horn Point Lab, Ctr Environm Sci, POB 775, Cambridge, MD 21613 USA.

${ }^{4}$ Thunen Inst Sea Fisheries, Palmaille 9, D-22767 Hamburg, Germany.

${ }^{5}$ Deltares, Boussinesqweg 1, NL-2629 HV Delft, Netherlands.

${ }_{7}^{6}$ Aarhus Univ, Dept Biosci, Frederiksborgvej 399,POB 358, DK-4000 Roskilde, Denmark.

${ }^{7}$ Univ Cambridge, Dept Zool, Downing St, Cambridge CB2 3EJ, England.

${ }^{8}$ LEI Wageningen UR, Alexanderveld 5, NL-2585 DB The Hague, Netherlands.

${ }^{9}$ Inst Francais Rech Exploitat Mer, Dept Ressources Biol \& Environm, Quai Gambetta BP 699, F-62321 Boulogne Sur Mer, France.

${ }^{10}$ IMARES, Haringkade 1, NL-1976 CP ljmuiden, Netherlands.

${ }^{11}$ Food \& Agr Org, Fisheries \& Aquaculture Policy \& Resources Div, Viale Terme Caracalla, I-00153 Rome, Italy.

*Corresponding author : Ana M. Queiros, email address : anqu@pml.ac.uk

\begin{abstract}
:
The Paris Conference of Parties (COP21) agreement renewed momentum for action against climate change, creating the space for solutions for conservation of the ocean addressing two of its largest threats: climate change and ocean acidification (CCOA). Recent arguments that ocean policies disregard a mature conservation research field and that protected areas cannot address climate change may be oversimplistic at this time when dynamic solutions for the management of changing oceans are needed. We propose a novel approach, based on spatial meta-analysis of climate impact models, to improve the positioning of marine protected areas to limit CCOA impacts. We do this by estimating the vulnerability of ocean ecosystems to CCOA in a spatially explicit manner and then co-mapping human activities such as the placement of renewable energy developments and the distribution of marine protected areas. We test this approach in the NE Atlantic considering also how CCOA impacts the base of the food web which supports protected species, an aspect often neglected in conservation studies. We found that, in this case, current regional conservation plans protect areas with low ecosystem-level vulnerability to CCOA, but disregard how species may redistribute to new, suitable and productive habitats. Under current plans, these areas remain open to commercial extraction and other uses. Here, and worldwide, ocean conservation strategies under CCOA must recognize the long-term importance of
\end{abstract}


these habitat refuges, and studies such as this one are needed to identify them. Protecting these areas creates adaptive, climate-ready and ecosystem-level policy options for conservation, suitable for changing oceans.

Keywords : climate change, conservation, COP21, ecosystem model, habitat, marine spatial planning, ocean, ocean acidification, species distribution, warming 
50 The perspective that ocean conservation cannot be used to limit the overwhelming pressures that

51 climate change and ocean acidification (CCOA) exert on marine systems (Nagelkerken \&

52 Connell, 2015) is still often held (Hilborn, 2015). In parallel, research efforts to improve the

53 effectiveness of marine conservation under climate change have rapidly increased in recent years

54 (Côté \& Darling, 2010, Levy \& Ban, 2013, Maxwell et al., 2015). However, studies addressing

55 the ecosystem-level impacts of CCOA, in the context of the multiple human uses of the ocean

56 within which conservation takes place, are still largely absent. Solutions for ocean conservation

57 are now needed when many ecosystem components are simultaneously and indirectly affected by

58 long-term CCOA and other human activities, driving declines across large numbers of species at

59 the same time (Audzijonyte et al., 2016, Griffith et al., 2012, Hobday \& Pecl, 2014). Crucially,

60 how can we plan for foodweb changes that would affect many protected (and unprotected)

61 species, such as regional reduction in plankton productivity driven by CCOA (Nagelkerken \&

62 Connell, 2015)? Complex, ecosystem-level changes caused by CCOA may continue to occur

63 across the foodweb, no matter how limited commercial extraction is inside marine reserves.

64 Many governments (including the USA, UK, Chile and New Zealand) are betting on the closure

65 of vast areas of the ocean to fisheries to meet the need to reduce overfishing, and increase the sustainability of marine food resources. Some agree that this reduction in local stressors such as

67 fisheries can also, in some cases, improve resistance to climate stressors (Carilli et al., 2010). 
These efforts have thus been welcomed, but do they unwittingly offer false hope? Beyond the need to secure larger areas of the ocean against commercial extraction, conservation strategies must embrace novel climate change research, which reveals that curbing CCOA impacts on marine foodwebs may require more comprehensive aims. Alongside human activities such as

72 fisheries (Campbell et al., 2014); nutrient loading (Wakelin et al., 2015); aquaculture

73 (UKMMAS, 2010); and energy production (Rourke et al., 2010); CCOA impacts marine species

74 both directly by altering life history processes and vital rates, as well as indirectly, through

75 changes in the distribution of suitable habitat and food availability (i.e. primary production,

76 Audzijonyte et al., 2016, Blanchard et al., 2012, Cheung et al., 2011). Consequently, solutions

77 for conservation that protect against CCOA cannot focus solely on the protection of declining

78 species. Consideration must be given to how CCOA impacts processes affecting population

79 sustainability locally but, equally, to the relationships between these processes and habitat

80 characteristics, which are also be impacted by CCOA.

81 A growing body of theory and mechanistic evidence has demonstrated that the responses of

82 populations to stressors such as CCOA not only depend on the gradient of change experienced,

83 but also on how that gradient relates to the range of variability that populations have experienced

84 historically for each of these variables (Peck et al., 2009, Somero, 2010). A prerequisite for the

85 local populations to persist in the short-term, failure of which negates the possibility for long-

86 term adaptation to occur (Somero, 2010), is acquiring sufficient food from the environment to

87 support energetically costly stress response pathways (Queirós et al., 2015b, Thomsen et al.,

88 2013). Sufficient food uptake therefore allows the option to allocate energy where needed, i.e. to

89 respond to stress in addition to fueling population dynamic processes such as growth and

90 reproduction (Calosi et al., 2013, Gaylord et al., 2015, Pörtner \& Farrell, 2008). Food 
91 availability can therefore dictate whether or not a given organism is able to withstand

92 environmental changes such as ocean acidification, and deserves attention in conservation

93 planning. A greater focus of conservation research in considering impacts on primary

94 productivity, alongside those on multiple species, should thus yield more effective conservation

95 aims in light of ecosystem-level impacts of CCOA: 1) because it would ensure that food

96 resources are available to organisms in communities experiencing environmental change through

97 CCOA; and 2) because protecting areas of the ocean that make important contributions to

98 primary and secondary production have positive outcomes to other human uses of the ocean

99 (Brown et al., 2010).

100 Changes in system productivity, in plankton communities and other groups at the base of the 101 foodweb, associated with CCOA (Nagelkerken \& Connell, 2015) have seldom been considered 102 in conservation research, perhaps because of the challenges of collecting and integrating these 103 data to answer management questions. Nonetheless, to adequately inform policy, conservation 104 science must broaden to include ecosystem-level vulnerability, e.g. to recommend areas for 105 protection where species could be able to remain in (or locate to) suitable habitat, and thrive 106 productively. We argue that, to this end, habitat modeling (Gormley et al., 2013) and similar 107 approaches can be powerful tools to integrate novel CCOA knowledge, which are underused in 108 conservation research and policy advice. We exemplify here the potential benefits of more 109 comprehensively using these tools in ocean conservation.

110 New technological approaches to data collection and analysis can support dynamic ocean 111 management (Lewison et al., 2015, Maxwell et al., 2015). Yet, ocean observations alone have 112 limited value in the long-term forecasting of systems when conditions are expected to depart 113 considerably from those observed historically due to the long-term impacts of climate change 
114 (Barnsley, 2007, Payne et al., 2015). Conversely, the combined use of models that simulate 115 multiple levels of the ocean foodweb resolved in time and space can be used to explore: 1) how 116 levels of CCOA not yet observed could in the long-run impact marine life and the distribution of

117 productivity that supports it (Queirós et al., 2015b); and 2) whether ocean conservation and 118 exploitation strategies may be optimized to address environmental stressors and their future 119 effects (Jones \& Cheung, 2014, Levin et al., 2009, Sumaila et al., 2015). However, the 120 application of such models in conservation research is often narrowly focused. For example, the 121 effects of changes in sea temperature are often examined in isolation (Molinos et al., 2015) 122 despite evidence that ocean acidification is a co-occurring global stressor and can strongly 123 modify species vulnerability to thermal stress (Kroeker et al., 2013, Nagelkerken \& Connell, 124 2015). Furthermore, vulnerability of local species to CCOA can be exacerbated by human uses 125 of the marine environment (Carilli et al., 2010, Planque et al., 2010) but a holistic view of their 126 combined impacts is rarely considered by conservation studies. Finally, focus is frequently placed 127 on single or small subsets of species or ecosystem properties (e.g. Gormley et al., 2013), although 128 the current management paradigm in the United States and in Europe requires decisions to be 129 weighed based on their impacts on whole ecosystems and not just based on single human 130 activities or ecosystem components (EC, 2008, EU, 2014, NOC, 2013, Rice, 2013).

131 Here, we overcome these shortcomings using a novel approach to extract common patterns in 132 long-term projections from a large ensemble of ecosystem models forced with climate change 133 and, where possible, ocean acidification, taking into account additional human activities. Using 134 global change scenarios and a range of modeling projections for the middle of the $21^{\text {st }}$ century, 135 we present an analysis focused on the NE Atlantic continental shelf that identifies areas where 136 consensus exists across models regarding the occurrence of large and directional change of 137 ecosystem components (hereafter, "hotspots of change"). The large model ensemble analyzed 
138 here covered as many ecosystem components and trophic levels as possible from 54 distinct

139 models. Various global scenarios of change in $\mathrm{CO}_{2}$ emissions, as defined by the

140 Intergovernmental Panel on Climate Change at the time of the study (IPCC, 2007), allowed

141 changes in ocean temperature, oxygen, $\mathrm{pH}$ and productivity to be simulated. Changes in riverine

142 nutrient loadings were also considered based on assumptions of human use consistent with the

143 IPCC's representative concentration pathways (Langmead et al., 2007). Similarly to others

144 (Hobday \& Pecl, 2014), we propose that hotspots of change pinpoint long-term ecosystem-level

145 CCOA vulnerabilities in this region and should receive special consideration in conservation

146 plans. Alongside other individually threatened or declining habitats or species, response to

147 CCOA requires that priority should be given to: i) protect areas where ecosystem-level change

148 will be significant and positive (i.e. increasing with time) and thus where productivity will

149 remain high; ii) protect areas where the ecosystem will not change significantly due to CCOA;

150 and iii) shifting (the often limited) resources for conservation away from areas where negative,

151 CCOA-driven changes are expected to occur and/or where productivity is expected to decrease,

152 because limiting commercial extraction in those areas may not increase the sustainability of local

153 populations. We suggest that making these distinctions may initiate a new stage for conservation

154 research-policy dialogue that, in addition to traditional goals, responds dynamically to limit ocean

155 impacts of CCOA.

156 By considering a diversity of models and potential trajectories of environmental change, we

157 aimed to provide a balanced view of possible futures for the NE Atlantic shelf driven by CCOA.

158 To best address inherent variation among model setups, we used a novel spatial approach to a

159 well-established statistical technique (random effects meta-analysis, Borenstein et al., 2011).

160 Specifically, we estimated changes over time driven by CCOA at the ecosystem-level, by

161 constructing meta-analysis models which, at each point in space, quantified the agreement in the 
162 changes measured across the populations of various species and ecosystem components, as

163 measured by each individual model. This approach circumvents the difficulty of summarizing

164 ecosystem-level information from the aggregate estimates of a large number of models which, in

165 our opinion, has hindered the integrated use of model-derived estimates in conservation advice to

166 policy. Furthermore, we statistically quantify the uncertainty of the overall model analysis, by

167 providing an easily understandable measure of confidence to our findings (significance testing)

168 which is especially useful in informing policy. Accordingly, significant change measured at the

169 ecosystem-level in each point in space indicates the presence of hotspots of change, reflecting

170 uniformity in the response(s) of the assessed ecosystem component(s) to environmental variation

171 in the various independent models analyzed, and lending confidence to the results. We compare

172 the estimated distribution of hotspots of change with projected spatial planning actions in the

173 region, focusing on areas currently (or foreseen to be) designated for conservation and offshore

174 energy developments (windfarms). The approach combines a large amount of ecosystem-level

175 information into one analysis to answer straightforward questions relevant to develop climate-

176 ready conservation policies: which areas will, in the long term, not change due to CCOA, or

177 support positive change (i.e. higher productivity) for marine species and habitats? This study is

178 the first attempt to identify areas of high ecosystem-level vulnerability to CCOA through the use

179 of a spatially explicit meta-analysis of a model ensemble. Our results highlight future challenges

180 for marine conservation policy in areas experiencing multiple human pressures as well as

181 undergoing rapid climate-driven change. The co-mapping of hotspots of ecosystem-level

182 vulnerability to CCOA and human uses can help pave the way for effective and well informed

183 marine spatial planning. We did not consider the potentially additional impact of present and

184 future fishing on the assessed ecosystem components given that our primary aim was to address 
185 CCOA driven impacts as the background against which other human actions on the marine 186 environment, including conservation, could be investigated.

\section{$187 \quad$ Materials and methods}

188 Input data

189 All model projections analyzed were produced or made available within the EU research project

190 VECTORS (Vectors of Change in Oceans and Seas Marine Life, Impact on Economic Sectors, 191 FP7/2007-2013), during which a large number of projections were produced to assess the impacts 192 of pressures of change on specific components of marine ecosystems (Teal et al., 2013).

193 Modelling outputs were scoped to include any level of the foodweb and relevant ecosystem 194 processes within the domain of the NE Atlantic Continental Shelf. Each dataset had to comprise 195 two comparable states of the ecosystem; i.e. a baseline and an effect state that could be used to 196 quantify change. Typically, the data structure included projections for a "present" and a "future" 197 time slice (5-10 yrs each) for each given model, simulated under a given scenario of future 198 change, e.g. a specific IPCC special report emissions scenario (IPCC, 2007). Each dataset 199 included spatial arrays of mean and standard deviation for each variable, for each time slice. We 200 gathered 63 outputs, originating from 54 distinct models, which are summarized in Table SI 201 (supporting information). Detailed descriptions of each model can be found in references within 202 it.

203 Modelled data on "jellyfish" were not available in this study, reflecting the limited sampling and 204 understanding of this group of organisms that currently exists. However, jellyfish play an 205 important role in coastal and shelf seas impacted by climate change, diverting carbon from higher 
206 trophic levels (Robinson \& Graham, 2013) and should be considered in similar studies in the

207 future.

208 Meta-analyses of model projections

209 Because the different models used here had different resolutions and gridding systems,

210 aggregation to a coarser, common grid was required. Accordingly, all model outputs considered

211 were aggregated across 164 standard statistical rectangles $\left(1.0^{\circ} \times 0.5^{\circ}\right.$ lon $\mathrm{x}$ lat $)$ used by the

212 International Council for the Exploration of the Sea (ICES). One separate meta-analysis model

213 for each cell of the NE Atlantic Continental Shelf domain was then calculated across datasets,

214 following the procedures documented in Borenstein et al. (2011), which provides a

215 comprehensive synthesis of methodologies, strengths and caveats. The following procedure was

216 employed, per domain cell.

217 "Dataset" hereafter refers to the mean, standard deviation and number of observations for each

218 model output detailed in Table SI $(n=63)$, for a given domain cell. "Change" was initially

219 calculated using Hedge's g (Hedges, 1981), the unbiased standardized mean difference estimator,

220 under a fixed effects model structure. This metric considers the mean, standard deviation and the

221 number of observations in each of the slices (usually temporal slices, supporting information

222 Table SI for time span covered in each case). The calculation of individual effect-sizes (i.e. per

223 model, per domain cell) was conventionalized across analyses so that positive change indicated

224 an increase of the given variable in the future in relation to present, in that specific cell of the

225 domain, and vice-versa. For example, positive Hedge's g for primary productivity indicated that

226 this process was higher in the future, in a specific cell of the domain. We then estimated the

227 effects across datasets (i.e. the summary-effects) per domain cell, considering that in this case we 
228 expected not one, but a family of possible effect-sizes, given the diversity of datasets considered.

229 This attribute of the data justified the use of a random-effects meta-analysis model. Accordingly,

230 the variance of the effect-size for each dataset was re-calculated as the sum of: i) the variance of

231 Hedge's g within each dataset, for each cell (as before); and ii) the variance between datasets, for

232 that cell. The latter $\left(\tau^{2}\right)$ was estimated using the DerSimonian-Laird method (DerSimonian \&

233 Laird, 1986). The variances of the summary-effects were then used to calculate confidence

234 intervals for the summary-effects in each cell, and hence to test their departure from zero, under a

235 normal distribution. Statistically significant departure from zero for summary-effects was

236 therefore considered to be indicative of significant change. The analysis was carried out across all

237 the datasets together $(n=63)$ and, in this case, significant change indicated ecosystem-level

238 vulnerability. Additionally, two subgroup analyses were undertaken, separately: one considering

239 fish (or high trophic level) datasets $(\mathrm{n}=52)$; and one considering lower trophic level datasets

240 ( $\mathrm{n}=11$, Table SI). The spatial coverage of datasets can be found in supporting information

241 figure.S1. Preliminary analyses indicated that the number of datasets influenced the estimate of

242 variance between datasets $\left(\tau^{2}\right)$. As the latter is used to estimate confidence intervals for summary-

243 effects, all analyzes including fish datasets excluded domain edge areas (grey, Fig.S1b) where the

244 number of available datasets was contrastingly lower.

245 The reasoning to investigate summary-effects within subsets of meta-analysis datasets has been

246 discussed at length elsewhere, and is beyond the scope of this study (Lyons et al., 2015). Study

247 selection for meta-analysis should be made transparently and a priori, guided by the research

248 question investigated, as done here. This study aimed to provide a balanced view of long-term,

249 ecosystem-level dynamics in the NE Atlantic Shelf. Accordingly, all modelling outputs available

250 to the authors at the time of the analysis, were used. However, the influence of individual datasets 
251 on summary-effects could be expected to vary, due to the context dependency of individual 252 modelling results (Jones et al., 2013). Two precautions were implemented in meta-analysis 253 protocols to address this matter. Specifically, meta-analysis is not a vote counting procedure, in

254 that not all datasets count equally. When a summary-effect was calculated (across datasets), more 255 confidence was given to variables for which the mean over the time period analyzed varied less 256 within and between datasets. Larger weight was also given to estimates calculated over a larger 257 number of observations (or larger model sampling), because they are assumed to provide a wider 258 coverage of the dynamics of the process simulated. These two considerations thus reduce the 259 influence of information derived from poorly constrained models, or less comprehensive datasets, 260 on summary-effects.

261 It is noteworthy that in following this aim of including all available datasets in this analysis, we 262 included data on the phenology of plankton species (supporting information Table SI), because 263 these are important indicators of ecosystem dynamics, particularly in coastal systems (Zhang et $264 a l ., 2015)$. However, changes in these processes (i.e. changes in the timing of primary

265 productivity and Phaeocystis sp. peaks across years) may be difficult to interpret within the 266 present statistical framework. Since North Sea phytoplankton blooms have been predicted to 267 occur earlier (not later) by the middle of the century, we decided a priori to treat this direction of 268 change as "negative" (Friocourt et al., 2012).

269 Co-mapping of spatial planning actions

270 The spatial planning actions considered in this analysis are the construction of windfarms and the

271 delimitation of marine protected areas. The NE Atlantic Continental Shelf is shared between

272 several countries' exclusive economic zones (EEZ), and each country is responsible for marine 
273 planning within it. The scenarios presented here do not necessarily reflect actual plans or legally

274 authorized decisions, but are based on ongoing discussions in the countries. Future projections

275 for the distribution of windfarms and marine protected areas ("MPAs") were estimated based on

276 Bartelings et al. (2013), Schulze et al. (2012) and on Delavenne (2012). The latter was

277 specifically used to support the definition of conservation areas and windfarms in the Eastern

278 English Channel (to include the French EEZ). Nature conservation areas were defined here

279 including the Natura 2000 areas for the British, French, Dutch, Danish, and German EEZ,

280 designated under the EU's Habitats and Birds Directives. OSPAR (2013) was used to verify the

281 projected distribution of protected areas. To project the expansion of windfarms by the middle of

282 the $21^{\text {st }}$ century, given a political scenario favoring green energy, all the planned, pre-planned and

283 search areas of the French, UK German, Dutch and Danish planned windfarms were included. In

284 the Eastern English Channel, only the 12-, 6-, and 3-mile restricted coastal zones were considered

285 to be restrictive to fishing activities (in the present and in the short-term future), and only those

286 were implemented as marine protected areas in the projections. These data were aggregated at

287 the ICES statistical rectangle resolution, to match the meta-analyses datasets. This aggregation

288 considered only whether either of these actions was projected for each domain cell, and not the

289 actual area of each cell expected to be covered by each action. Consideration of cell fractions was

290 not possible given the need to aggregate projections produced by the different models under

291 different gridding systems. The projected future distributions of windfarms and conservation

292 areas were then overlaid onto spatial domains illustrating the results of each of the meta-analyses

293 results (Fig. 1a-c) to highlight potential conflict areas.

294 We were not able to include fishing pressure in our analysis though recent work has demonstrated 295 that the impacts of climate on marine species may be impacted by extent to which communities 
296 are exploited through fisheries (Blanchard et al., 2012). Future expansions of this work should 297 therefore consider such information.

\section{$298 \quad$ Results}

299 Ecosystem-level vulnerability to climate change and ocean acidification of the NE Atlantic shelf

300 Our analysis shows that areas currently (or that are planned to be) designated for conservation in 301 the NE Atlantic shelf predominantly cover regions that do not exhibit ecosystem-level 302 vulnerability to CCOA (on average, more than $90 \%$ of protected areas, Figure 1, open circles 303 overlaid by upright triangles). Conversely, areas projected to be most vulnerable to CCOA-driven 304 ecosystem-level change (black dots, Fig. 1) are largely unprotected, and yet may come to represent important areas of high productivity in the future (both at the base of the food web and

306 for demersal fish; black dots over pink, Fig.1). Hotspots of negative change estimated based on 307 projections for fish ( $\mathrm{n}=52$ models) occurred along the E and NE coast of the UK (Fig. 1a and 308 Table SI) and illustrate loss of suitable habitat or lower productivity as a result of CCOA. The 309 proportion of these areas under (or foreseen for) conservation is low (21\%) and the majority of 310 these will also host windfarms, according to ongoing dialogue in the respective countries (see 311 methods; Fig. 1a, inverted triangles and black dots overlaid on blue). Hotspots of positive change 312 - areas where fish are projected to re-distribute to - occurred in the NE region of our study, near 313 the Norwegian coast (Fig. 1a, black dots overlaid on pink, Fig.S1c). Less than a tenth of those 314 areas are currently under (or foreseen for) conservation and half of these coincide with areas that 315 will in the future host windfarms (Fig. 1a, upright and inverted triangles and black dots overlaid 316 on pink). The potential displacement of fish species to the deeper NE areas of the North Sea shelf 317 identified here is consistent with a movement towards areas of the seabed that remain suitable 
318 habitat given current projections of future warming trend for the area. The warming trend will be 319 less pronounced in these deeper, seasonally-stratified areas (Dulvy et al., 2008, Holt et al., 2012), 320 representing potential habitat refuges for the majority fish species we analyzed, which are benthic 321 or demersal (supporting information Table SI). Increased seasonal stratification in these areas 322 could also impact these species negatively, through decreased supply of oxygen (Whitney et al., 323 2007), nutrient and larval dispersal. However, potential negative effects of seasonal stratification 324 leading to decreased habitat suitability would have been considered by $38 \%$ of the fish 325 projections analyzed here (supporting information Table SI, see also Cheung et al., 2011, 326 Fernandes et al., 2013).

327 Significant negative changes across the base of the foodweb ( $\mathrm{n}=11$ model projections; Table SI) 328 were found in the NW part of the NE Atlantic shelf (Fig.1b), and none of these areas are 329 currently under (or foreseen for) conservation. The co-occurrence of negative hotspots for fish 330 and lower trophic level models north of Aberdeen Bank and the North Atlantic Front of the North 331 Sea (Fig.1a and b, and Fig.S1c) suggest strong foodweb connection in this area, which is 332 supported by empirical evidence (Cubillos-Moreno et al., in prep). Positive change, reflecting 333 increases in both nutrients and productivity at the base of the foodweb was only significant in one 334 site in the Skagerrak, hosting both protected areas and windfarms (Fig.1b). Most other positive 335 changes at the base of the foodweb occurred in coastal areas in the southern North Sea (German 336 Bight and eastern English Channel), although this was not sufficiently consistent across modeling 337 projections, or large enough, to be statistically significant. However, $38 \%$ of the fish models 338 considered here are forced by primary production simulations, so potential increases in primary 339 production would be captured in Fig.1a. Present (and planned) conservation in the NE Atlantic 340 seems to encompass primarily areas where no significant change is projected with regard to 
341 climate or nutrient loading of coastal areas, the majority of which will also host windfarms

342 (Fig.1b, upright and inverted triangles overlaid).

343 When all datasets were pooled (63 projection sets from 54 models, Fig. 1c), hotspots of change

344 largely reflected projected changes where the responses of lower and higher trophic levels

345 converged, indicating ecosystem-level vulnerability (e.g. NW of the domain in Fig.1a-c). We also

346 found that conservation efforts currently focus on areas which will not exhibit significant

347 ecosystem-level CCOA change by the mid of the $21^{\text {st }}$ century. In parallel, only $15 \%$ of areas

348 where the ecosystem will respond significantly and positively to CCOA are currently under (or

349 foreseen for) protection in the NE Atlantic shelf, and half of those that are will also host

350 windfarms. This indicates that areas potentially responding positively to CCOA are open to other

351 types of pressures, such as fisheries. 

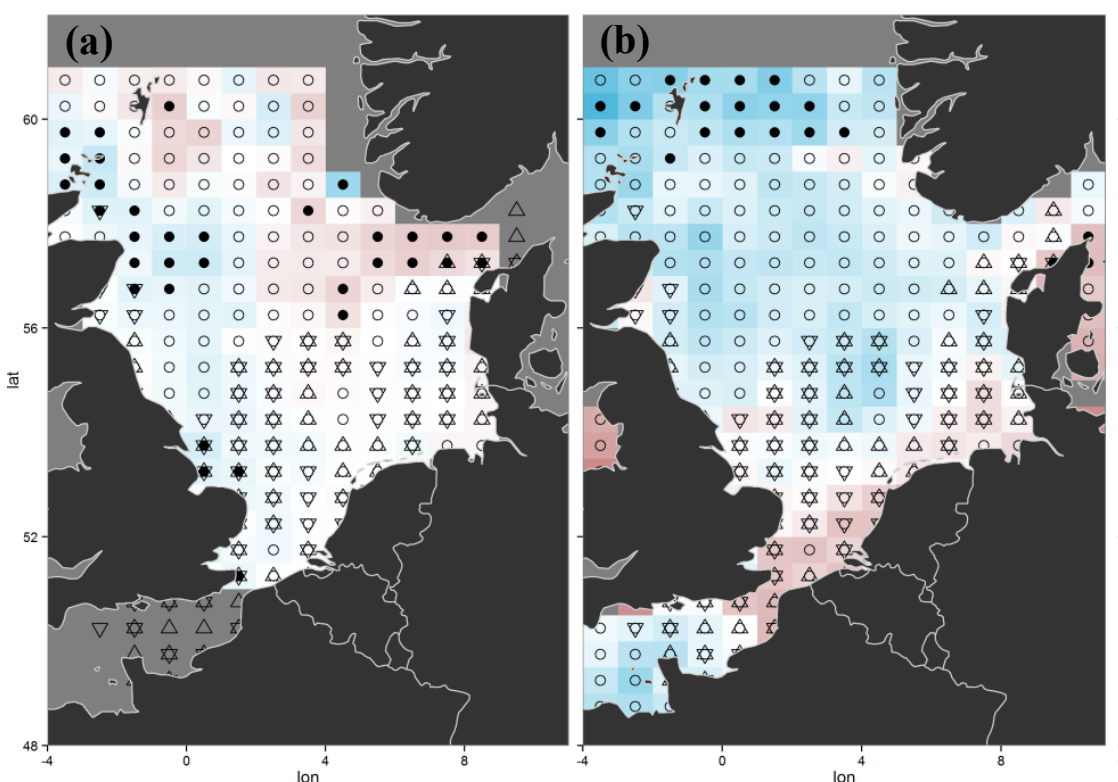

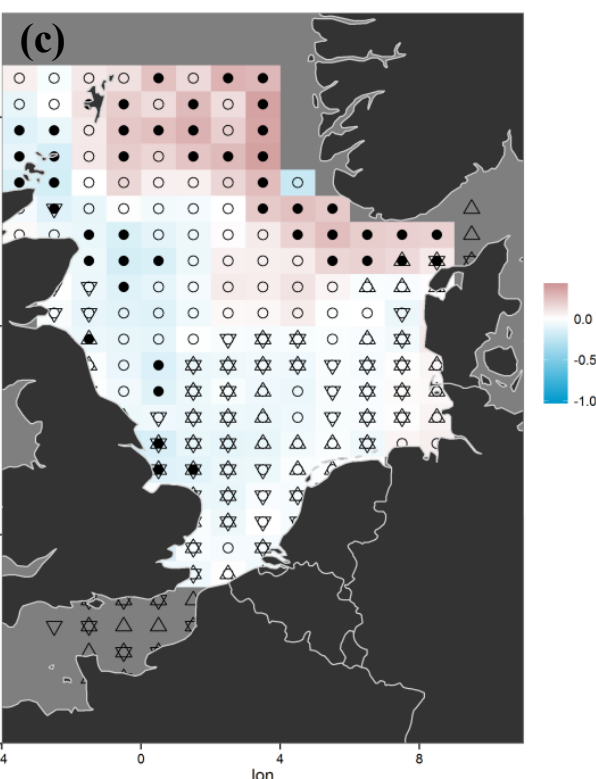

353

Figure 1: Ecosystem-level vulnerability to CCOA by 2050 calculated across three model ensembles. Color shading indicates positive (pink) or negative (blue) change across analyzed model projections. Black dots indicate hotspots of change: areas where there was consensus in the direction and magnitude of change over time across models for fish (a), lower trophic levels (b) and all ecosystem components (c). The future distribution of conservation areas (black upright triangles) and windfarms (inverted black triangles) is superimposed. Open circles superimposed on color indicate areas where there was no consistency across models and/or changes were small in individual datasets. Gray cells omit areas with low number of datasets (c and a) and those not covered by the models analyzed $(a, b$ and $c)$. We argue that areas where consensus exists across models on the occurrence of large and positive change of ecosystem components driven by CCOA (marked by pink color overlaid by black dots) should be considered as conservation priorities. 


\section{Discussion}

362 This study suggests that conservation policies in the NE Atlantic shelf are, by and large, not

363 focused on areas where species and habitats are expected to be sharply impacted by CCOA, as analyzed here. Specifically, we found a low degree of overlap between identified negative hotspots of change, for both high and low trophic levels, and the current and planned positioning of MPAs. Whilst this is clearly a positive outcome, our analysis also highlights that areas which may become important for many species and for primary productivity by the middle of the $21^{\text {st }}$ century are currently not protected and thus open to other types of pressures, such as commercial extraction and energy exploration. In this area, and worldwide, not protecting areas into which species could re-distribute as the location of suitable habitat is modified by CCOA, could have important adverse consequences for natural populations of fish and other mobile fauna (Cheung et al., 2011, Raab et al., 2013). Conversely, protecting from commercial extraction areas where significant adverse, long-term and climate-driven change could occur (e.g. by loss of suitable habitat) may be perceived as serving little purpose given what we know about CCOA (Nagelkerken \& Connell, 2015). Reduction of manageable pressures such as fisheries to improve the ability of some species to better withstand environmental stressors has been endorsed by some (Carilli et al., 2010). However, focusing on changes on pressures alone may not be sufficient to protect multiple species assemblages experiencing multiple stressors like CCOA. Recent empirical evidence and advances in physiological theory and modelling indicate that co-occurrence of stressors such as CCOA, and intrinsic differences among species will influence responses (Gaylord et al., 2015, Griffith et al., 2012, Kroeker et al., 2013, Kroeker et al., 2010, Nagelkerken \& Connell, 2015, Pörtner \& Farrell, 2008). Environmental change beyond individual tolerance thresholds for each stressor result in individual-level trade-offs in the allocation of energy between stress response pathways and processes supporting population dynamics and 
dispersal (Calosi et al., 2013, Parker et al., 2013, Queirós et al., 2015b). These, in turn, determine short- and medium-turn plasticity of populations within communities, and longterm adaptive potential, the understanding of which is still limited (Calosi et al., 2013, Morley et al., 2009, Queirós et al., 2015b). This is because the majority of the knowledge base is still comprised of studies on single generations of individual species, responding to single stressors, which often neglect also how inter-specific interactions may impact on the development of adaptive strategies within populations (Queirós et al., 2015b, Riebesell \& Gattuso, 2015). From first principles, the uptake of sufficient energetic resources from the environment (i.e. food) to support the higher metabolic costs endured during environmental change is a fundamental part of local survival of individual species in the short- and mediumterm, before adaptation can take place (Melzner et al., 2011, Queirós et al., 2015b, Thomsen et al., 2013). Assessing changes in primary productivity and other elements at the base of the foodweb, such as nutrient availability, as proxies for food availability could therefore be important. Ensuring high food availability could be seen as an insurance policy for the conservation of multiple-species assemblages in a multi-stressor future ocean. The relative value of considering the base of the foodweb under climate change has only seldom been discussed in conservation studies (e.g. Brown et al., 2010). A solid theoretical and empirical evidence base now supports the perspective that projecting species distributions to support MPA design in the face of CCOA requires consideration of these changes at the base of the foodweb too, as done here.

Our findings for the NE Atlantic shelf suggest that CCOA, as considered here, will create distinct areas where lower and upper trophic levels respond differently to this change. The joint consideration of upper and lower trophic levels in MPA design and adaptation in this region, and potentially in others, may thus require extending the focus of conservation to areas other than those which may be of more obvious relevance to the (generally high trophic 
411 level) species protected. Similarly, the statistical approach used here led to the identification

412 of ecosystem-level hotspots of change which were not immediately predictable from the analyses focused on specific levels of the foodweb. Whole ecosystem conservation may too require the allocation of resources to areas other than those immediately obvious from a focus on the sensitivities of single species, or ecosystem components. Here, and potentially in other ocean areas, a re-evaluation of which ecosystem components will be most important to conserve, and which of those are protected under current spatial plans in the face of CCOA, may therefore be needed. Climate change and ocean acidification are rapidly shifting the conservation goal posts through unprecedented and widespread change in marine ecosystems (Pörtner et al., 2014, Riebesell \& Gattuso, 2015). We argue that experimental research and modelling tools that integrate this knowledge, similar to those presented here, and by others, can support needed innovation in marine conservation research, and contribute to the development of solutions that address these challenges (cf. Hilborn, 2015, Lubchenco \& Grorud-Colvert, 2015).

Enforcing conservation requires the allocation of limited resources at the national and international level, and influences economic sectors such as fisheries, shipping, tourism and energy production (Christie et al., 2014). Providing adequate advice to conservation policy under these circumstances therefore requires a better understanding of climate change and ocean acidification impacts in a multi-species and multi-use context. Meeting this aim requires the use of tools which consider these multiple elements simultaneously. The combined use of estimates from different types of models undertaken here provides a holistic view of ecosystems where the impacts of conservation, management, and global change scenarios can be explored (Hollowed et al., 2013, Queirós et al., 2015a). Use of these models to inform advice for policy has, however, been hindered by uncertainty associated with climate modeling projections, but the research community has begun addressing this issue 
436 (Cheung et al., 2016, Payne et al., 2015). It is worth highlighting that the majority of models

437 available, including some of those used here, does not yet consider the specific impacts of more recently recognized pressures such as OA and the increased use of the ocean for renewable energy developments. For instance, the full life-cycle analysis (construction, operation, and decommissioning) of potential ocean impacts of windfarms is unquantified and remains a critical gap in knowledge to be filled (Papathanasopoulou et al., 2015). We found that the small proportion of areas we identified as responding positively to CCOA which are already considered for protection under current spatial plans were frequently colocated in the vicinity of existing (or planned) windfarms. A rapid need to decarbonize the global economy alongside as of yet limited knowledge of the impacts of windfarms on the physical properties of ocean (Cazenave et al., 2016) suggest that this too is a an area of marine conservation research requiring fast development. In parallel, large emphasis has alreaty been placed on developing models to help project the impacts of CCOA and coastal development on ocean ecosystems (Holt et al., 2012, Jørgensen et al., 2012, Queirós et al., 2015b). Integrated analyses of multiple human uses of the marine environment and CCOA in a multi-species context, as presented here, are crucial to develop ecosystem-based management solutions for the oceans, of which conservation is just one part.

The new Sustainable Development Goals put forward by the United Nations are a clear call to "take urgent action to combat climate change and its impacts" and to "conserve and sustainably use the oceans": it is urgent that the conservation research community considers these aims together. This approach could become part of a climate-ready solution for marine conservation that improves marine spatial planning in the face of CCOA, by helping to identify marine areas with ecosystem-level vulnerability; by identifying areas where ecosystem-level CCOA impacts may not be significant in the long term (Côté \& Darling, 2010); and identifying problematic areas, where hotspots of positive change associated with 
461 CCOA coincide with manageable human uses of the ocean. Expansion of the temporal 462 elements of this approach could support the development of more adaptive conservation

463 solutions. The goal is clear: $10 \%$ of marine areas to be protected by 2020 (Lubchenco \& 464 Grorud-Colvert, 2015). Let these areas also best insure against climate change and ocean 465 acidification.

\section{Acknowledgments}

467 This work was funded within the European Community's Seventh Framework Programme's 468 (FP7/2007-2013, Grant Agreement No. 266445) project Vectors of Change in Oceans and 469 Seas Marine Life, Impact on Economic Sectors (VECTORS). The authors are grateful for 470 insightful discussions with other colleagues undertaken during the VECTORS project, which 471 stimulated the development of the rationale for this study. AMQ, PJS, MCA and IJA 472 acknowledge support from the UK Natural Environment Research Council and UK 473 Department for Environment, Food and Rural Affairs (grant number NE/L003279/1, Marine 474 Ecosystems Research Programme). All model projections used in this study are available 475 from the authors on request, through the public repository Open Earth. 


\section{References}

Audzijonyte A, Fulton E, Haddon M et al. (2016) Trends and management implications of human-influenced life-history changes in marine ectotherms. Fish and Fisheries.

Barnsley MJ (2007) Environmental modeling: a practical introduction, CRC Press.

Bartelings H, Hamon KG, Tomson N (2013) Coastal fisheries fleet model - FishRent. In: Deliverable D3.3 COEXIST project grant agreement no 245178. pp 22, Netherlands.

Blanchard JL, Jennings S, Holmes R et al. (2012) Potential consequences of climate change for primary production and fish production in large marine ecosystems. Philosophical Transactions of the Royal Society B: Biological Sciences, 367, 2979-2989.

Blauw AN, Los HF, Bokhorst M, Erftemeijer PL (2009) GEM: a generic ecological model for estuaries and coastal waters. Hydrobiologia, 618, 175-198.

Borenstein M, Hedges LV, Higgins JP, Rothstein HR (2011) Introduction to meta-analysis, John Wiley \& Sons.

Brown C, Fulton E, Hobday A et al. (2010) Effects of climate-driven primary production change on marine food webs: implications for fisheries and conservation. Global Change Biology, 16, 1194-1212.

Butenschön M, Clark J, Aldridge J et al. (2015) ERSEM 15.06: a generic model for marine biogeochemistry and the ecosystem dynamics of the lower trophic levels. Geoscientific Model Development Discussions, 8, 7063-7187.

Butenschön M, Kay S (2013) Future scenarios of the biogeochemistry of the three Regional Seas (Project report No. D5.1.1). In: VECTORS of Change in Oceans and Seas Marine Life, Impact on Economic Sectors. pp 39, Plymouth Marine Laboratory.

Calosi P, Rastrick SP, Lombardi C et al. (2013) Adaptation and acclimatization to ocean acidification in marine ectotherms: an in situ transplant experiment with polychaetes 

at a shallow $\mathrm{CO}_{2}$ vent system. Philosophical Transactions of the Royal Society B: Biological Sciences, 368, 20120444.

503

Campbell MS, Stehfest KM, Votier SC, Hall-Spencer JM (2014) Mapping fisheries for marine spatial planning: Gear-specific vessel monitoring system (VMS), marine conservation and offshore renewable energy. Marine Policy, 45, 293-300.

Carilli JE, Norris RD, Black B, Walsh SM, Mcfield M (2010) Century-scale records of coral 507 growth rates indicate that local stressors reduce coral thermal tolerance threshold. Global Change Biology, 16, 1247-1257.

Cazenave PW, Torres R, Allen JI (2016) Unstructured grid modelling of offshore wind farm impacts on seasonally stratified shelf seas. Progress in Oceanography, 145, 25-41.

Cheung WW, Jones MC, Reygondeau G, Stock CA, Lam VW, Frölicher TL (2016) Structural uncertainty in projecting global fisheries catches under climate change. Ecological Modelling, 325, 57-66.

Cheung WWL, Dunne J, Sarmiento JL, Pauly D (2011) Integrating ecophysiology and plankton dynamics into projected maximum fisheries catch potential under climate change in the Northeast Atlantic. ICES Journal of Marine Science, 68, 1008-1018.

Christie N, Smyth K, Barnes R, Elliott M (2014) Co-location of activities and designations: A means of solving or creating problems in marine spatial planning? Marine Policy, 43, 254-261.

Côté IM, Darling ES (2010) Rethinking ecosystem resilience in the face of climate change. PLoS Biol, 8, e1000438.

Cubillos-Moreno JC, Villate-Moreno ML, Cisewski B, Keyl F, Sell AF (in prep) Impacts of the North Atlantic inflow on macrozooplankton and ichthyoplankton assemblages in the North Sea: a case study conducted in spring of 2012. 
Delavenne J (2012) Conservation des habitats marins soumis à des usages multiples: Méthodes, objectifs et contraintes pour l'optimisation d'un réseau d'Aires Marines Protégées en Manche orientale. Doctorate thesis, Université du Littoral Côte d'Opale, $170 \mathrm{pp}$.

Dersimonian R, Laird N (1986) Meta-analysis in clinical trials. Controlled clinical trials, 7, 177-188.

Dulvy NK, Rogers SI, Jennings S, Stelzenmüller V, Dye SR, Skjoldal HR (2008) Climate change and deepening of the North Sea fish assemblage: a biotic indicator of warming seas. Journal of Applied Ecology, 45, 1029-1039.

Dunne JP, Gnanadesikan A, Sarmiento JL, Slater RD (2010) Technical description of the prototype version (v0) of tracers of phytoplankton with allometric zooplankton (TOPAZ) ocean biogeochemical model as used in the Princeton IFMIP model. Biogeosciences, 7, 3593.

Ec (2008) Marine Strategy Framework Directive. In: 2008/56/EC (ed Eu) pp 19-40, Official Journal of the European Union.

$\mathrm{Eu}$ (2014) Establishing a framework for maritime spatial planning. In: 2014/89/EU. Brussels, Official Journal of the European Union.

Fernandes JA, Cheung WW, Jennings S et al. (2013) Modelling the effects of climate change on the distribution and production of marine fishes: accounting for trophic interactions in a dynamic bioclimate envelope model. Global Change Biology, 19, $2596-2607$.

Friocourt Y, Skogen M, Stolte W, Albretsen J (2012) Marine downscaling of a future climate scenario in the North Sea and possible effects on dinoflagellate harmful algal blooms. Food Additives \& Contaminants: Part A, 29, 1630-1646. 
549 Gaylord B, Kroeker KJ, Sunday JM et al. (2015) Ocean acidification through the lens of ecological theory. Ecology, 96, 3-15.

551 Gormley KS, Porter JS, Bell MC, Hull AD, Sanderson WG (2013) Predictive habitat modelling as a tool to assess the change in distribution and extent of an OSPAR priority habitat under an increased ocean temperature scenario: consequences for marine protected area networks and management. PLOS ONE, 8, e68263.

Griffith GP, Fulton EA, Gorton R, Richardson AJ (2012) Predicting Interactions among Fishing, Ocean Warming, and Ocean Acidification in a Marine System with WholeEcosystem Models. Conservation Biology, 26, 1145-1152.

Hedges LV (1981) Distribution theory for Glass's estimator of effect size and related estimators. Journal of Educational and Behavioral Statistics, 6, 107-128.

Hilborn R (2015) Marine Protected Areas miss the boat. Science, 350, 1326.

Hobday AJ, Pecl GT (2014) Identification of global marine hotspots: sentinels for change and vanguards for adaptation action. Reviews in Fish Biology and Fisheries, 24, 415-425.

Hollowed AB, Barange M, Beamish RJ et al. (2013) Projected impacts of climate change on marine fish and fisheries. ICES Journal of Marine Science: Journal du Conseil, 70, 1023-1037.

Holt J, Harle J, Proctor R et al. (2009) Modelling the global coastal ocean. Philosophical Transactions of the Royal Society A: Mathematical, Physical and Engineering Sciences, 367, 939-951.

Holt J, Hughes S, Hopkins J et al. (2012) Multi-decadal variability and trends in the temperature of the northwest European continental shelf: A model-data synthesis. Progress in Oceanography, 106, 96-117. 
572 Ipcc (2007) Climate Change 2007: The Physical Science Basis. (eds Solomon S, Qin D, United Kingdom and New York, NY, USA.

Jones MC, Cheung WW (2014) Multi-model ensemble projections of climate change effects on global marine biodiversity. ICES Journal of Marine Science: Journal du Conseil, fsu172.

Jones MC, Dye SR, Fernandes JA, Frölicher TL, Pinnegar JK, Warren R, Cheung WW (2013) Predicting the impact of climate change on threatened species in UK waters. PLoS ONE, 8, e54216.

Jørgensen C, Peck MA, Antognarelli F et al. (2012) Conservation physiology of marine fishes: advancing the predictive capacity of models. Biology Letters, 8, 900-903.

Kroeker KJ, Kordas RL, Crim R et al. (2013) Impacts of ocean acidification on marine organisms: quantifying sensitivities and interaction with warming. Global Change Biology, 19, 1884-1896.

Kroeker KJ, Kordas RL, Crim RN, Singh GG (2010) Meta-analysis reveals negative yet variable effects of ocean acidification on marine organisms. Ecology Letters, 13, $1419-1434$.

Langmead O, Mcquatters-Gollop A, Mee L (2007) European lifestyles and marine ecosystems: exploring challenges for managing Europe's seas, University of Plymouth Marine Institute.

Lesser G, Roelvink J, Van Kester J, Stelling G (2004) Development and validation of a threedimensional morphological model. Coastal engineering, 51, 883-915.

Levin PS, Fogarty MJ, Murawski SA, Fluharty D (2009) Integrated ecosystem assessments: developing the scientific basis for ecosystem-based management of the ocean. PLoS biology, 7, e1000014. 
Levy JS, Ban NC (2013) A method for incorporating climate change modelling into marine conservation planning: An Indo-west Pacific example. Marine Policy, 38, 16-24.

Lewison R, Hobday AJ, Maxwell S et al. (2015) Dynamic ocean management: identifying the critical ingredients of dynamic approaches to ocean resource management. Bioscience, 65, 486-498.

Lubchenco J, Grorud-Colvert K (2015) Making waves: The science and politics of ocean protection. Science, 350, 382-383.

Lyons D, Arvanitidis C, Blight A et al. (2015) There are no whole truths in meta-analyses: all their truths are half truths. Global Change Biology, 22, 968-971.

Maar M, Møller EF, Gürkan Z, Jónasdóttir SH, Nielsen TG (2013) Sensitivity of Calanus spp. copepods to environmental changes in the North Sea using life-stage structured models. Progress in Oceanography, 111, 24-37.

Maar M, Møller EF, Larsen J et al. (2011) Ecosystem modelling across a salinity gradient from the North Sea to the Baltic Sea. Ecological Modelling, 222, 1696-1711.

Maxwell SM, Hazen EL, Lewison RL et al. (2015) Dynamic ocean management: Defining and conceptualizing real-time management of the ocean. Marine Policy, 58, 42-50.

Melzner F, Stange P, Trübenbach K et al. (2011) Food supply and seawater p CO 2 impact calcification and internal shell dissolution in the blue mussel Mytilus edulis. PLoS ONE, 6, e24223.

Molinos JG, Halpern BS, Schoeman DS et al. (2015) Climate velocity and the future global redistribution of marine biodiversity. Nature Climate Change, DOI:10.1038/nclimate2769.

Møller EF, Maar M, Jónasdóttir SH, Nielsen TG, Tönnesson K (2012) The effect of changes in temperature and food on the development of Calanus finmarchicus and Calanus helgolandicus populations. Limnology and Oceanography, 57, 211-220. 
622 Morley SA, Tan KS, Day RW, Martin SM, Po“Rtner H-O, Peck LS (2009) Thermal

623

624

625

626

627

628

629

630

631

632

633

634

635

636

637

638

639

640

641

642

643

644

645

646 dependency of burrowing in three species within the bivalve genus Laternula: a latitudinal comparison. Marine Biology, 156, 1977-1984.

Nagelkerken I, Connell SD (2015) Global alteration of ocean ecosystem functioning due to increasing human $\mathrm{CO}_{2}$ emissions. Proceedings of the National Academy of Sciences, $112,13272-13277$

Noc (2013) National ocean policy implementation plan. (ed Council NO), Washington.

Ospar (2013) Status Report on the OSPAR Network of Marine Protected Areas. In: Biodiversity Series. pp 64, OSPAR Commission.

Papathanasopoulou E, Beaumont N, Hooper T, Nunes J, Queirós AM (2015) Energy systems and their impacts on marine ecosystem services. Renewable and Sustainable Energy Reviews, 52, 917-926.

Parker LM, Ross PM, O'connor WA, Pörtner HO, Scanes E, Wright JM (2013) Predicting the response of molluscs to the impact of ocean acidification. Biology, 2, 651-692.

Payne MR, Barange M, Cheung WW et al. (2015) Uncertainties in projecting climate change impacts in marine ecosystems. ICES Journal of Marine Science.

Peck LS, Clark MS, Morley SA, Massey A, Rossetti H (2009) Animal temperature limits and ecological relevance: effects of size, activity and rates of change. Functional Ecology, $248-256$.

Philippart C, Anadón R, Danovaro R et al. (2007) Climate change impacts on the European marine and coastal environment-ecosystem approach. Position Paper, 9.

Planque B, Fromentin J-M, Cury P, Drinkwater KF, Jennings S, Perry RI, Kifani S (2010) How does fishing alter marine populations and ecosystems sensitivity to climate? Journal of Marine Systems, 79, 403-417.

Pörtner HO, Farrell AP (2008) Physiology and Climate Change. Science, 322, 690-692. 
647 Pörtner HO, Karl DM, Boyd PW et al. (2014) Ocean systems: Impacts, Adaptation, and

648

649

650

651

652

653

654

655

656

657

658

659

660

661

662

663

664

665

666

667

668

669

670

Vulnerability. Part A: Global and Sectoral Aspects. In: Contribution of Working Group II to the Fifth Assessment Report of the Intergovernmental Panel on Climate Change. (eds Field CB, Barros VR, Dokken DJ, Mach KJ, Mastrandrea MD, Bilir TE, Chatterjee M, Ebi KL, Estrada YO, Genova RC, Girma B, Kissel ES, Levy AN, S. Maccracken, Mastrandrea PR, White LL) pp 411-484. Cambridge, United Kingdom and New York, NY, USA, Cambridge University Press.

Queirós AM, Bruggeman J, Stephens N et al. (2015a) Placing biodiversity in ecosystem models without getting lost in translation. Journal of Sea Research, 98, 83-90.

Queirós AM, Fernandes JA, Faulwetter S et al. (2015b) Scaling up experimental ocean acidification and warming research: from individuals to the ecosystem. Global Change Biology, 21, 130-143.

Raab K, Llope M, Nagelkerke LA et al. (2013) Influence of temperature and food availability on juvenile European anchovy Engraulis encrasicolus at its northern boundary. Marine Ecology Progress Series, 488, 233-245.

Rice J (2013) Evolution of international commitments for fisheries sustainability. ICES Journal of Marine Science: Journal du Conseil, fst078.

Riebesell U, Gattuso J-P (2015) Lessons learned from ocean acidification research. Nature Climate Change, 5, 12-14.

Robinson KL, Graham WM (2013) Long-term change in the abundances of northern Gulf of Mexico scyphomedusae Chrysaora sp. and Aurelia spp. with links to climate variability. Limnology and Oceanography, 58, 235-253.

Rourke FO, Boyle F, Reynolds A (2010) Tidal energy update 2009. Applied Energy, 87, 398409. 
671 Schulze T, Schulte K, Hamon KG (2012) Report on economic analysis in coastal fisheries on

672

673

674

675

676

677

678

679

680

681

682

683

684

685

686

687

688

689

690

691

692

693 the basis of revenue for individual profession and fishing trips. In: Deliverable D3.2 COEXIST project grant agreement no 245178. pp 18, Netherlands.

Somero G (2010) The physiology of climate change: how potentials for acclimatization and genetic adaptation will determine 'winners' and 'losers'. The Journal of experimental biology, 213, 912-920.

Sumaila UR, Lam VW, Miller DD et al. (2015) Winners and losers in a world where the high seas is closed to fishing. Scientific reports, $\mathbf{5}$.

Teal LR, Sell A, Peck M et al. (2013) Mechanisms of change in species distribution and productivity (Project report No D2.2.3). In: VECTORS of Change in Oceans and Seas Marine Life, Impact on Economic Sectors. pp 89, IMARES, Wageningen University.

Thomsen J, Casties I, Pansch C, Körtzinger A, Melzner F (2013) Food availability outweighs ocean acidification effects in juvenile Mytilus edulis: laboratory and field experiments. Global Change Biology, 19, 1017-1027.

Ukmmas (2010) Charting Progress 2 Feeder Report Productive Seas. . (eds Saunders J, Mckie J) pp 472, Department for Environment Food and Rural Affairs on behalf of the United Kingdom Marine Monitoring and Assessment Strategy (UKMMAS).

Van Meijgaard E, Van Ulft L, Van De Berg W, Bosveld F, Van Den Hurk B, Lenderink G, Siebesma A (2008) The KNMI regional atmospheric climate model RACMO version 2.1, Koninklijk Nederlands Meteorologisch Instituut.

Wakelin SL, Artioli Y, Butenschön M, Allen JI, Holt JT (2015) Modelling the combined impacts of climate change and direct anthropogenic drivers on the ecosystem of the northwest European continental shelf. Journal of Marine Systems, 152, 51-63. 
694 Whitney FA, Freeland HJ, Robert M (2007) Persistently declining oxygen levels in the 695 interior waters of the eastern subarctic Pacific. Progress in Oceanography, 75, 179$696 \quad 199$.

697 Yool A, Popova EE, Coward AC, Bernie D, Anderson TR (2013) Climate change and ocean acidification impacts on lower trophic levels and the export of organic carbon to the deep ocean. Biogeosciences Discussions, 10, 3455-3522.

700

Zhang Q, Warwick RM, Mcneill CL, Widdicombe CE, Sheehan A, Widdicombe S (2015) An

701 unusually large phytoplankton spring bloom drives rapid changes in benthic diversity and ecosystem function. Progress in Oceanography, 137, 533-545.

703

704 


\section{Supporting information}

Table SI: Datasets used in model ensemble. "HT" - high trophic level. "LT" - low trophic level. "SDM" - species distribution model.

The specific model configurations used are indicated (A-F) and refer to: A) Size-spectrum-Dynamic bioclimate envelope model using environmental forcing from the coupled hydrodynamic-biogeochemical model NEMO-MEDUSA 2.0 (Fernandes et al., 2013, IPCC, 2007, Yool et al., 2013); B) Dynamic bioclimate envelope model using environmental forcing from the coupled hydrodynamic-biogeochemical model WCRP-CMIP3 - GFDL-ESM 2.1 (Cheung et al., 2011, Dunne et al., 2010, IPCC, 2007, Jones et al., 2013); C) Species specific life-history stage-structured models using environmental forcing from the coupled hydrodynamic-biogeochemical model DMI-BSHcmod - ERGOM (Maar et al., 2013, Maar et al., 2011, Møller et al., 2012, Philippart et al., 2007); D) Coupled hydrodynamic-biogeochemical model Delf-3D using modules FLOW and DELWAQ(BLOOM/GEM) and environmental forcing from RACMO 2.1(Blauw et al., 2009, Friocourt et al., 2012, IPCC, 2007, Lesser et al., 2004, Van Meijgaard et al., 2008); E) Coupled hydrodynamic-biogeochemical model POLCOMS - ERSEM (Butenschön et al., 2015, Butenschön \& Kay, 2013, Holt et al., 2009, IPCC, 2007); F) Size-class mechanistic species distribution model based on General Additive Modelling, using coupled hydrodynamic-biogeochemical model POLCOMS-ERSEM (Butenschön et al., 2015, Butenschön \& Kay, 2013, IPCC, 2007, Teal et al., 2013). "CC”: climate change. "CCOA”: climate change and ocean acidification. 


\begin{tabular}{|c|c|c|c|c|c|c|c|c|c|c|}
\hline $\begin{array}{l}\text { Foodweb } \\
\text { level }\end{array}$ & Model type & Configuration & Scenario & Slices & Variable & Species & $\begin{array}{c}\text { Common } \\
\text { name }\end{array}$ & Size & $\begin{array}{c}\text { Model } \\
\text { considers } \\
\text { CC }\end{array}$ & $\begin{array}{l}\text { Model } \\
\text { considers } \\
\text { CCOA }\end{array}$ \\
\hline HT & Fish SDM & $A$ & $\mathrm{~A} 1 \mathrm{~b}$ & $\begin{array}{l}\text { baseline: } 2001-2010 \\
\text { effect: } 2050-2059\end{array}$ & Abundance & $\begin{array}{l}\text { Lepidorhombus } \\
\text { boscii }\end{array}$ & $\begin{array}{l}\text { Fourspotted } \\
\text { megrim }\end{array}$ & NA & Yes & Yes \\
\hline HT & Fish SDM & B & $\mathrm{A} 2$ & $\begin{array}{l}\text { baseline: } 1981 \text { - } 2000 \\
\text { effect: } 2041 \text { - } 2060\end{array}$ & Abundance & $\begin{array}{l}\text { Pollachius } \\
\text { virens }\end{array}$ & Saithe & NA & Yes & Yes \\
\hline HT & Fish SDM & $A$ & $\mathrm{~A} 1 \mathrm{~b}$ & $\begin{array}{l}\text { baseline: } 2001-2010 \\
\text { effect: } 2050-2059\end{array}$ & Abundance & Brosme brosme & Tusk & NA & Yes & Yes \\
\hline $\mathrm{HT}$ & Fish SDM & A & $\mathrm{A} 1 \mathrm{~b}$ & $\begin{array}{l}\text { baseline: } 2001-2010 \\
\text { effect: } 2050-2059\end{array}$ & Abundance & $\begin{array}{l}\text { Culpea } \\
\text { harrengus }\end{array}$ & $\begin{array}{l}\text { Atlantic } \\
\text { herring }\end{array}$ & NA & Yes & Yes \\
\hline $\mathrm{HT}$ & Fish SDM & $A$ & $\mathrm{~A} 1 \mathrm{~b}$ & $\begin{array}{l}\text { baseline: } 2001-2010 \\
\text { effect: } 2050-2059\end{array}$ & Abundance & $\begin{array}{l}\text { Cyclopterus } \\
\text { lumpus }\end{array}$ & Lumpsucker & NA & Yes & Yes \\
\hline $\mathrm{HT}$ & Fish SDM & A & $\mathrm{A} 1 \mathrm{~b}$ & $\begin{array}{l}\text { baseline: } 2001-2010 \\
\text { effect: } 2050-2059\end{array}$ & Abundance & $\begin{array}{l}\text { Dicentrarchus } \\
\text { labrax }\end{array}$ & $\begin{array}{l}\text { European } \\
\text { seabass }\end{array}$ & NA & Yes & Yes \\
\hline $\mathrm{HT}$ & Fish SDM & $A$ & $\mathrm{~A} 1 \mathrm{~b}$ & $\begin{array}{l}\text { baseline: } 2001-2010 \\
\text { effect: } 2050-2059\end{array}$ & Abundance & $\begin{array}{l}\text { Engraulis } \\
\text { encrasicolus }\end{array}$ & $\begin{array}{l}\text { European } \\
\text { anchovy }\end{array}$ & NA & Yes & Yes \\
\hline HT & Fish SDM & B & $\mathrm{A} 2$ & $\begin{array}{l}\text { baseline: } 1981 \text { - } 2000 \\
\text { effect: } 2041 \text { - } 2060\end{array}$ & Abundance & Gadus morhua & Cod & NA & Yes & Yes \\
\hline HT & Fish SDM & $A$ & $\mathrm{~A} 1 \mathrm{~b}$ & $\begin{array}{l}\text { baseline: } 2001-2010 \\
\text { effect: } 2050-2059\end{array}$ & Abundance & Gadus morhua & Cod & NA & Yes & Yes \\
\hline HT & Fish SDM & $A$ & $A 1 b$ & $\begin{array}{l}\text { baseline: } 2001-2010 \\
\text { effect: } 2050-2059\end{array}$ & Abundance & $\begin{array}{l}\text { Glyptocephalus } \\
\text { cynoglossus }\end{array}$ & $\begin{array}{c}\text { Righteye } \\
\text { flounder/Wit } \\
\text { ch }\end{array}$ & NA & Yes & Yes \\
\hline HT & Fish SDM & $A$ & $\mathrm{~A} 1 \mathrm{~b}$ & $\begin{array}{l}\text { baseline: } 2001-2010 \\
\text { effect: } 2050-2059\end{array}$ & Abundance & $\begin{array}{l}\text { Katsuwonus } \\
\text { pelamis }\end{array}$ & $\begin{array}{l}\text { Skipjack } \\
\text { tuna }\end{array}$ & NA & Yes & Yes \\
\hline $\mathrm{HT}$ & Fish SDM & A & $\mathrm{A} 1 \mathrm{~b}$ & $\begin{array}{l}\text { baseline: } 2001-2010 \\
\text { effect: } 2050-2059\end{array}$ & Abundance & $\begin{array}{l}\text { Lepidorhombus } \\
\text { whiffiagonis }\end{array}$ & Megrim & NA & Yes & Yes \\
\hline
\end{tabular}




\begin{tabular}{|c|c|c|c|c|c|c|c|c|c|c|}
\hline HT & Fish SDM & $A$ & $A 1 b$ & $\begin{array}{l}\text { baseline: } 2001-2010 \\
\text { effect: } 2050-2059\end{array}$ & Abundance & $\begin{array}{l}\text { Merlangius } \\
\text { merlangus }\end{array}$ & Whiting & NA & Yes & Yes \\
\hline HT & Fish SDM & $A$ & $A 1 b$ & $\begin{array}{l}\text { baseline: } 2001-2010 \\
\text { effect: } 2050-2059\end{array}$ & Abundance & $\begin{array}{l}\text { Merluccius } \\
\text { merluccius }\end{array}$ & $\begin{array}{l}\text { European } \\
\text { hake }\end{array}$ & NA & Yes & Yes \\
\hline HT & Fish SDM & $A$ & $A 1 b$ & $\begin{array}{l}\text { baseline: } 2001-2010 \\
\text { effect: } 2050-2059\end{array}$ & Abundance & $\begin{array}{l}\text { Microchirus } \\
\text { variegatus }\end{array}$ & $\begin{array}{l}\text { Thickback } \\
\text { sole }\end{array}$ & NA & Yes & Yes \\
\hline HT & Fish SDM & $A$ & $A 1 b$ & $\begin{array}{l}\text { baseline: } 2001-2010 \\
\text { effect: } 2050-2059\end{array}$ & Abundance & $\begin{array}{l}\text { Micromesistius } \\
\text { poutassou }\end{array}$ & Blue whiting & NA & Yes & Yes \\
\hline HT & Fish SDM & $A$ & $\mathrm{~A} 1 \mathrm{~b}$ & $\begin{array}{l}\text { baseline: } 2001-2010 \\
\text { effect: } 2050-2059\end{array}$ & Abundance & Molva molva & Ling & NA & Yes & Yes \\
\hline HT & Fish SDM & $A$ & $A 1 b$ & $\begin{array}{l}\text { baseline: } 2001-2010 \\
\text { effect: } 2050-2059\end{array}$ & Abundance & $\begin{array}{l}\text { Pollachius } \\
\text { pollachius }\end{array}$ & Pollack & NA & Yes & Yes \\
\hline HT & Fish SDM & A & A1b & $\begin{array}{l}\text { baseline: } 2001-2010 \\
\text { effect: } 2050-2059\end{array}$ & Abundance & $\begin{array}{l}\text { Scomber } \\
\text { scombrus }\end{array}$ & $\begin{array}{l}\text { Atlantic } \\
\text { mackerel }\end{array}$ & NA & Yes & Yes \\
\hline HT & Fish SDM & $A$ & $A 1 b$ & $\begin{array}{l}\text { baseline: } 2001-2010 \\
\text { effect: } 2050-2059\end{array}$ & Abundance & $\begin{array}{l}\text { Squalus } \\
\text { acanthia }\end{array}$ & $\begin{array}{l}\text { Spiny } \\
\text { dogfish }\end{array}$ & NA & Yes & Yes \\
\hline LT & Copepod SDM & C & $+2^{\circ} \mathrm{C}$ & $\begin{array}{l}\text { baseline: } 2005 \\
\text { effect: } 2005+2^{\circ} \mathrm{C}\end{array}$ & Abundance & $\begin{array}{c}\text { Calanus } \\
\text { helgolandicus } \\
\text { (two quarters) }\end{array}$ & NA & NA & Yes & No \\
\hline LT & Copepod SDM & $\mathrm{C}$ & $+2^{\circ} \mathrm{C}$ & $\begin{array}{l}\text { baseline: } 2005 \\
\text { effect: } 2005+2^{\circ} \mathrm{C}\end{array}$ & Abundance: & $\begin{array}{c}\text { Calanus } \\
\text { finmarchicus } \\
\text { (two quarters) }\end{array}$ & NA & NA & Yes & No \\
\hline LT & $\begin{array}{l}\text { Coupled } \\
\text { biogeochemical } \\
\text { model }\end{array}$ & $\mathrm{D}$ & A1b & $\begin{array}{l}\text { baseline: } 1984 \text { - } 2003 \\
\text { effect: } 2031 \text { - } 2050\end{array}$ & $\begin{array}{c}\text { Chl a } \\
\text { biomass }\end{array}$ & NA & NA & NA & Yes & No \\
\hline LT & $\begin{array}{c}\text { Coupled } \\
\text { biogeochemical } \\
\text { model }\end{array}$ & D & $A 1 b$ & $\begin{array}{l}\text { baseline: } 1984 \text { - } 2003 \\
\text { effect: } 2031 \text { - } 2050\end{array}$ & $\begin{array}{c}\text { Chla } \\
\text { phenology } \\
\text { (peak) }\end{array}$ & NA & NA & NA & Yes & No \\
\hline LT & $\begin{array}{c}\text { Coupled } \\
\text { biogeochemical } \\
\text { model }\end{array}$ & $\mathrm{E}$ & $\mathrm{A} 2$ & $\begin{array}{l}\text { baseline: } 2000 \text { - } 2009 \\
\text { effect: } 2040 \text { - } 2049\end{array}$ & $\begin{array}{l}\text { Commnity } \\
\text { Production }\end{array}$ & NA & NA & NA & Yes & Yes \\
\hline
\end{tabular}




\begin{tabular}{|c|c|c|c|c|c|c|c|c|c|c|}
\hline LT & $\begin{array}{c}\text { Coupled } \\
\text { biogeochemical } \\
\text { model }\end{array}$ & $\mathrm{D}$ & A1b & $\begin{array}{l}\text { baseline: } 1984 \text { - } 2003 \\
\text { effect: } 2031 \text { - } 2050\end{array}$ & $\begin{array}{l}\text { Net primary } \\
\text { production }\end{array}$ & NA & NA & NA & Yes & No \\
\hline LT & $\begin{array}{c}\text { Coupled } \\
\text { biogeochemical } \\
\text { model }\end{array}$ & D & A1b & $\begin{array}{l}\text { baseline: } 1984 \text { - } 2003 \\
\text { effect: } 2031 \text { - } 2050\end{array}$ & $\begin{array}{l}\text { Phaeocystis } \\
\text { sp biomass }\end{array}$ & NA & NA & NA & Yes & No \\
\hline LT & $\begin{array}{c}\text { Coupled } \\
\text { biogeochemical } \\
\text { model }\end{array}$ & D & A1b & $\begin{array}{l}\text { baseline: } 1984-2003 \\
\text { effect: } 2031-2050\end{array}$ & $\begin{array}{c}\text { Phaeocystis } \\
\text { sp } \\
\text { phenology } \\
\text { (peak) }\end{array}$ & NA & NA & NA & Yes & No \\
\hline HT & Fish SDM & $\mathrm{F}$ & A2 and B1 & $\begin{array}{l}\text { baseline: } 2000 \text { - } 2009 \\
\text { effect: } 2040 \text { - } 2049\end{array}$ & $\begin{array}{l}\text { Size-class } \\
\text { mean } \\
\text { relative } \\
\text { local } \\
\text { abundance } \\
\text { Size-class }\end{array}$ & Culpea harrengus & $\begin{array}{l}\text { Atlantic } \\
\text { herring }\end{array}$ & $\mathrm{s}$ & Yes & No \\
\hline HT & Fish SDM & $\mathrm{F}$ & $A 2$ and $B 1$ & $\begin{array}{l}\text { baseline: } 2000 \text { - } 2009 \\
\text { effect: } 2040-2049\end{array}$ & $\begin{array}{l}\text { mean } \\
\text { relative } \\
\text { local } \\
\text { abundance }\end{array}$ & Eutrigla gurnardus & $\begin{array}{l}\text { Grey } \\
\text { gurnard }\end{array}$ & $\mathrm{s}$ & Yes & No \\
\hline HT & Fish SDM & $\mathrm{F}$ & $\mathrm{A} 2$ and $\mathrm{B} 1$ & $\begin{array}{l}\text { baseline: } 2000 \text { - } 2009 \\
\text { effect: } 2040 \text { - } 2049\end{array}$ & $\begin{array}{l}\text { Size-class } \\
\text { mean } \\
\text { relative } \\
\text { local } \\
\text { abundance }\end{array}$ & Eutrigla gurnardus & $\begin{array}{l}\text { Grey } \\
\text { gurnard }\end{array}$ & M & Yes & No \\
\hline HT & Fish SDM & $\mathrm{F}$ & $A 2$ and $B 1$ & $\begin{array}{l}\text { baseline: } 2000 \text { - } 2009 \\
\text { effect: } 2040-2049\end{array}$ & $\begin{array}{l}\text { Size-class } \\
\text { mean } \\
\text { relative } \\
\text { local } \\
\text { abundance }\end{array}$ & Eutrigla gurnardus & $\begin{array}{l}\text { Grey } \\
\text { gurnard }\end{array}$ & L & Yes & No \\
\hline HT & Fish SDM & $\mathrm{F}$ & $A 2$ and $B 1$ & $\begin{array}{l}\text { baseline: } 2000 \text { - } 2009 \\
\text { effect: } 2040-2049\end{array}$ & $\begin{array}{l}\text { Size-class } \\
\text { mean } \\
\text { relative } \\
\text { local } \\
\text { abundance }\end{array}$ & Gadus morhua & Cod & $S$ & Yes & No \\
\hline HT & Fish SDM & $\mathrm{F}$ & $\mathrm{A} 2$ and $\mathrm{B} 1$ & $\begin{array}{l}\text { baseline: } 2000 \text { - } 2009 \\
\text { effect: } 2040-2049\end{array}$ & $\begin{array}{l}\text { Size-class } \\
\text { mean } \\
\text { relative } \\
\text { local } \\
\text { abundance }\end{array}$ & Gadus morhua & Cod & MS & Yes & No \\
\hline
\end{tabular}




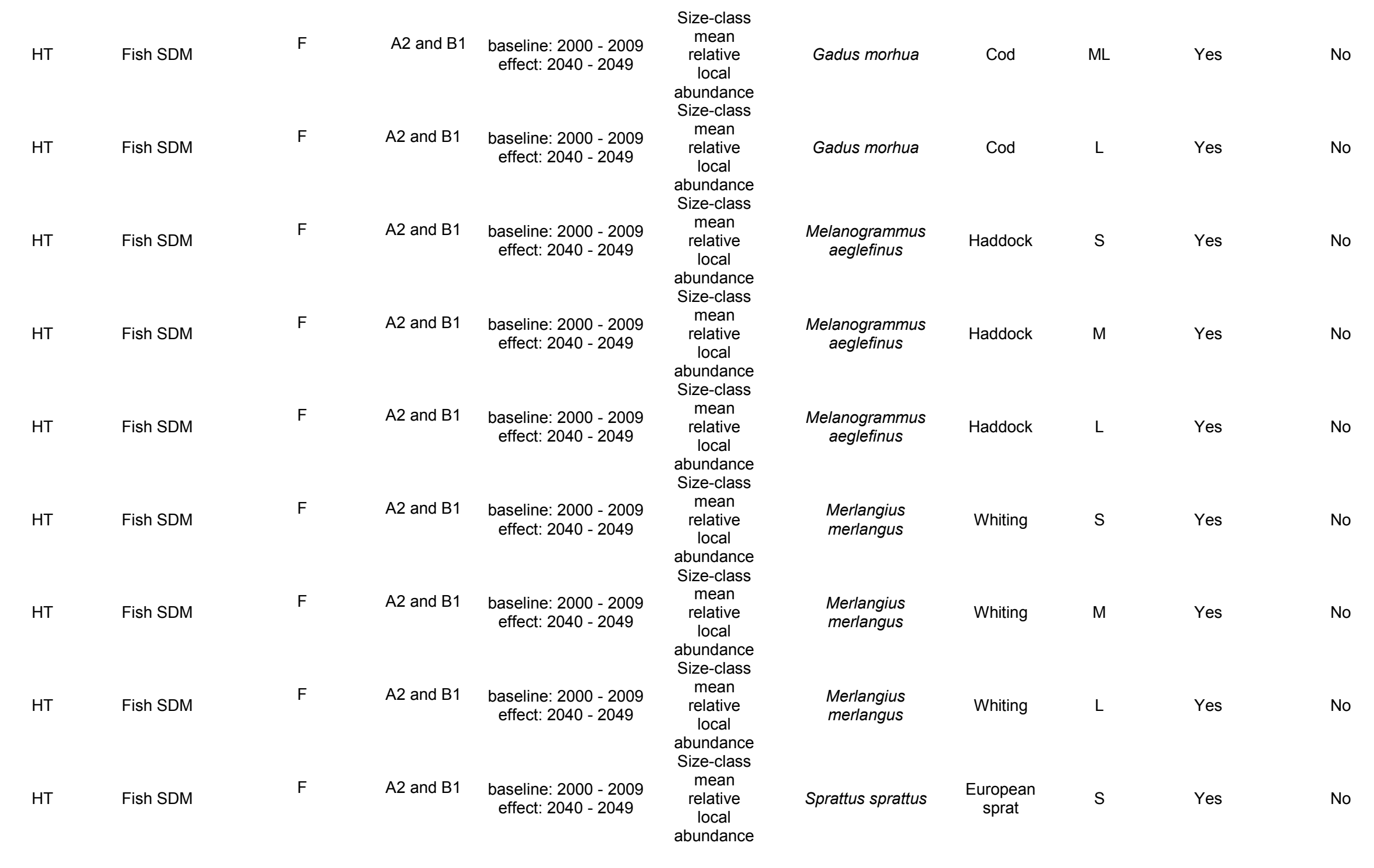


LT biogeochemical

$$
\text { model }
$$

A2 and B1 baseline: $2000-2009$ effect: 2040 - 2049

Size-class

mean

relative

local

abundance

Trisopterus

Norway pout

S

Yes

No

A2 baseline: 2000 - 2009 Surface effect: 2040 - 2049

NA

NA

NA

Yes

Yes 

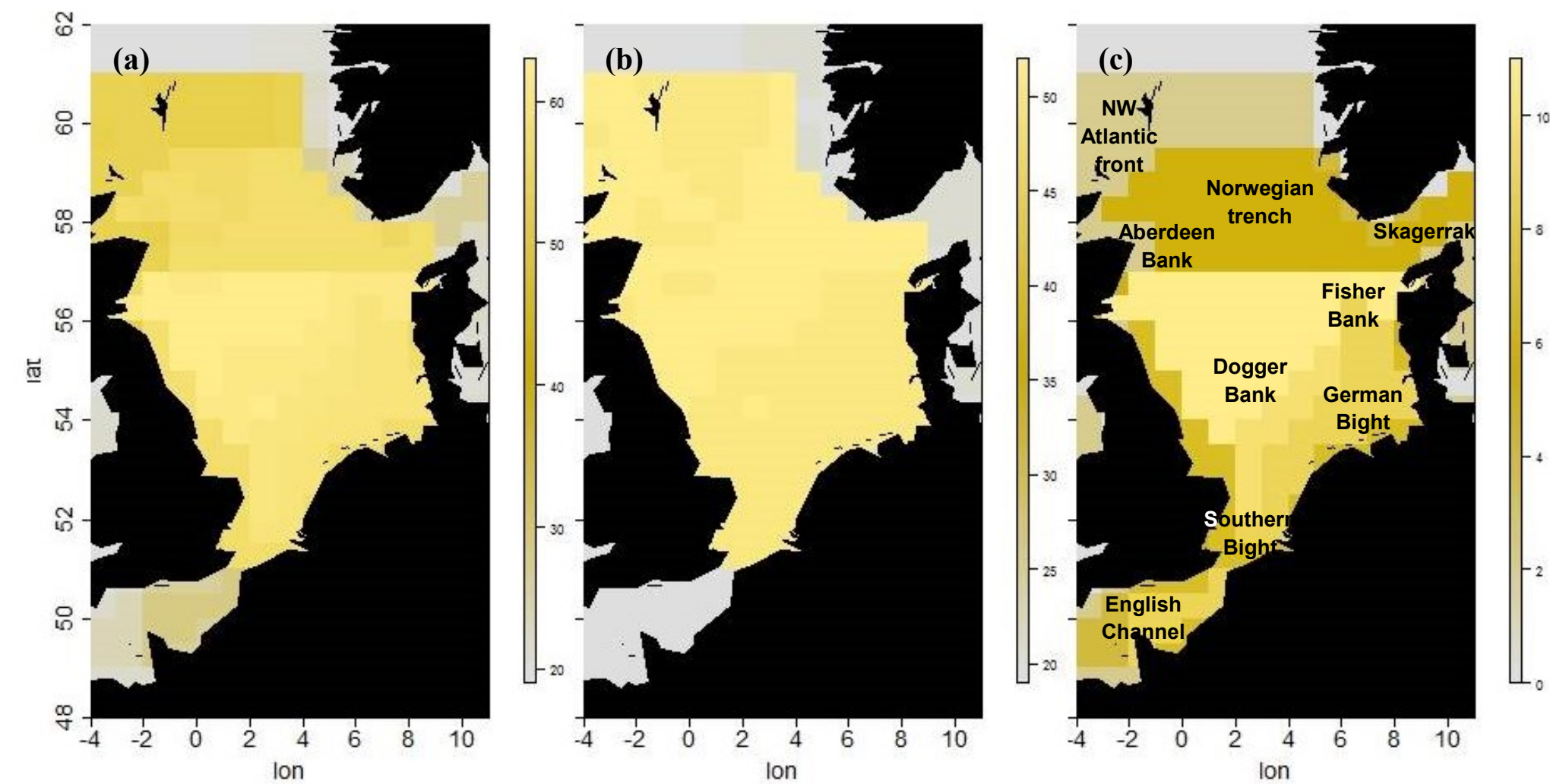

Figure. S1. The number of datasets in overall (a), fish (b) and lower trophic levels analyzes in each area (b), indicated by the color scales. 